\title{
A tandem Mannich addition-palladium catalyzed ring-closing route toward 4-substituted-3(2H)-furanones
}

\author{
Jubi John ${ }^{1}$, Eliza Târcoveanu ${ }^{1}$, Peter G. Jones ${ }^{2}$ and Henning Hopf ${ }^{* 1}$
}

\section{Full Research Paper}

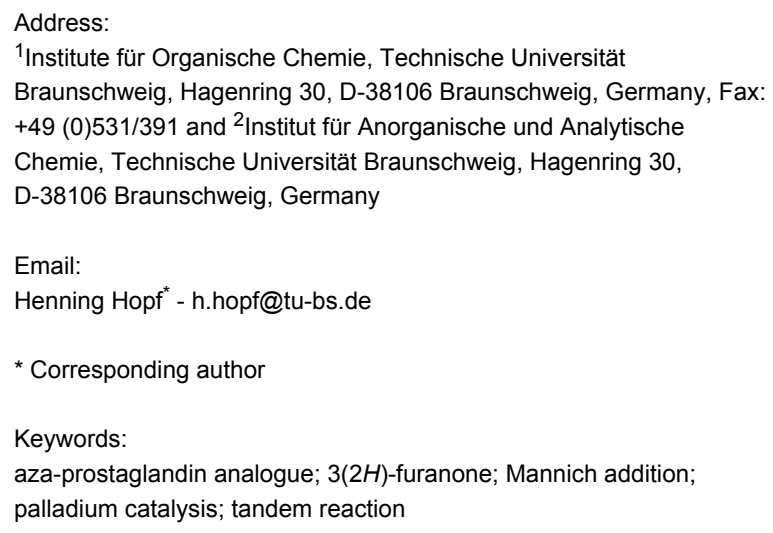

Keywords:

aza-prostaglandin analogue; $3(2 H)$-furanone; Mannich addition;

palladium catalysis; tandem reaction

\begin{abstract}
A facile route towards highly functionalized 3(2H)-furanones via a sequential Mannich addition-palladium catalyzed ring closing has been elaborated. The reaction of 4-chloroacetoacetate esters with imines derived from aliphatic and aromatic aldehydes under palladium catalysis afforded 4-substituted furanones in good to excellent yields. 4-Hydrazino-3(2H)-furanones could also be synthesized from diazo esters in excellent yields by utilising the developed strategy. We could also efficiently transform the substituted furanones to aza-prostaglandin analogues.
\end{abstract}

\section{Introduction}

Organic chemists welcome the introduction of facile tandem protocols because of the advantages of multiple bond formation in one-pot processes, which in turn makes the process economic and most importantly eco-friendly [1,2]. Conjugate addition is a very efficient tool used by synthetic chemists for the construction of carbon-carbon or carbon-heteroatom bonds [3]. Much effort has been invested to develop different variants of conjugate additions, both in catalyzed and non-catalyzed pathways.
$\alpha$-Halo ketones are known to react with zero-valent palladium like allyl halides to form oxa- $\pi$-allylpalladium complexes. Despite this fact, only minor attention has been paid to the formation of oxa- $\pi$-allylpalladium species from $\alpha$-halo ketones and to their reactivity [4-8]. In this report we describe the use of a tandem methodology involving a Mannich addition/palladiumcatalyzed ring-closing protocol for the facile synthesis of 4-substituted furanones. 
Since 3(2H)-furanones form the main component of many natural products and pharmaceutically important compounds (Figure 1) a number of routes for their synthesis [9-18] to have been reported in the literature.<smiles>Cc1ccc([C@@H]2C[C@H]2NC2=C(C(=O)O)C(=O)CO2)cc1</smiles>

antiallergic I<smiles>CC1(C)OC(c2ccccc2)=CC1=O</smiles>

bullatenone III<smiles>CCCCCCCNC1=C(CCCCc2ccc(OC)cc2)C(=O)CO1</smiles>

aza-prostaglandin analogue II<smiles>CC(=CCOc1ccc2ccc(=O)oc2c1)C1=CC(=O)C(C)(C)O1</smiles>

geiparvarin (antitumor) IV
Figure 1: Bioactive molecules I [19], II [26], III \& IV [21,22] with $3(2 H)$ furanone moiety.

Substituted 3(2H)-furanones exhibit a wide range of biological activities such as antiallergic, antiulcer, antiinflammatory, and antitumor activities or selective COX-2 inhibition [19-26]. Syn- thetic routes for the preparation of these compounds involve transformations of substituted $\alpha$-hydroxy-1,3-diketones [15,17], substituted furans [27-29], cyclization of allenic hydroxyketones [30], transition metal-catalyzed strategies ( $\mathrm{Au}$ [31-33], Pt [34,35], Pd [36], Hg [37]), etc. Lately, organo-catalyzed asymmetric routes towards $3(2 H)$-furanones from 4-haloacetoacetates and nitrostyrene were reported by Lu et al. [38] and Yan et al. [39].

We have recently reported on a palladium-catalyzed tandem methodology for the synthesis of 4-substituted-3(2H)-furanones from activated alkenes and 4-chloroacetoacetates (Scheme 1) [40].

The reaction was found to be general for a wide range of alkenes derived from aromatic and aliphatic aldehydes. The reaction proceeded via Michael addition of the acetoacetate to the alkene with a subsequent palladium-catalyzed ring closure of the primary adduct to form the furanone. In this paper, we report our investigations that extend the reaction to heteroatomcontaining electrophiles such as imines and diazo esters.

\section{Results and Discussion}

Following the work on nitrostyrenes, Yan et al. also reported a two-step asymmetric route towards 4-substituted-furanones from imines [41]. Recently Fructos et al. have shown that $N-p$ toluenesulfonyl-protected imines were better candidates for gold catalyzed Mannich addition of acetoacetates when

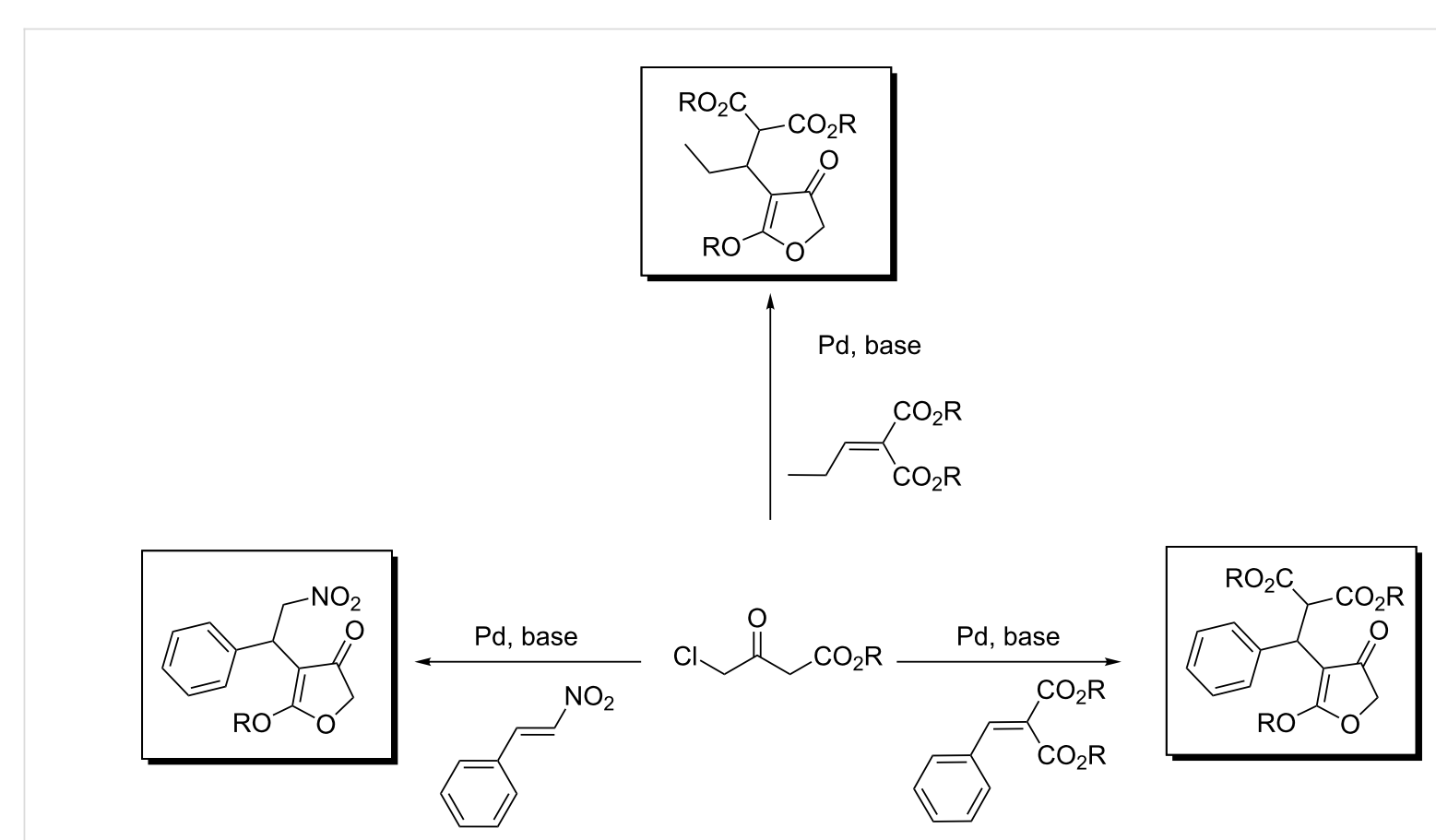


compared to $N$-Boc (tert-butoxycarbonyl) and $N$-PMP ( $p$-methoxyphenyl) imines [42]. Hence, we commenced our investigations with the reaction of tosylimine 1a and ethyl 4-chloroacetoacetate (2a) in the presence of $5 \mathrm{~mol} \%$ of $\mathrm{Pd}\left(\mathrm{PPh}_{3}\right)_{4}$ and 2.0 equivalents of $\mathrm{Na}_{2} \mathrm{CO}_{3}$, in dioxane at $50{ }^{\circ} \mathrm{C}$ for 10 hours. The reaction afforded 4 -substituted-3 $(2 H)$-furanone 3 in 57\% yield (Scheme 2). Interestingly, we could not detect the formation of diene-2,5-dicarboxylate 4 (formed by the dimerization of $\mathbf{2 a}$ ) as a side product, although this was observed previously in the reaction of activated alkenes [40] and 4-chloroacetoacetates.

Table 1 summarizes our efforts towards optimizing various reaction parameters with $\mathbf{1} \mathbf{a}$ and $\mathbf{2 a}$ as model substrates. Screening of bases revealed that $\mathrm{Na}_{2} \mathrm{CO}_{3}$ was more effective than either $\mathrm{K}_{2} \mathrm{CO}_{3}$ or $\mathrm{KO} t$ - $\mathrm{Bu}$ (Table 1, entries 1-3). When $\mathrm{KO} t$ - $\mathrm{Bu}$ was employed as base, byproduct 4 (formed by the dimerisation of 2a) was formed in higher amounts (Table 1, entry 3). From the tested catalysts, $\mathrm{Pd}\left(\mathrm{PPh}_{3}\right)_{4}$ and $\mathrm{Pd}_{2} \mathrm{dba}_{3} \cdot \mathrm{CHCl}_{3}$, and ligands, dppe and $\mathrm{P}(o \text {-furyl })_{3}$, the combination of $\mathrm{Pd}_{2} \mathrm{dba}_{3} \cdot \mathrm{CHCl}_{3}$ and dppe afforded the furanone 3 in $88 \%$ yield (Table 1 , entry 8 ). A solvent screen revealed that dioxane was best for the present transformation from which the product 3 was obtained in $88 \%$ yield (Table 1, entries 8-10). It was found that lowering the temperature had a negative influence on the yield as 3 was obtained only in $43 \%$ even after 24 hours when the substrates $\mathbf{1 a}$ and $\mathbf{2 a}$ were stirred in the presence of $\mathrm{Pd}_{2} \mathrm{dba}_{3} \cdot \mathrm{CHCl}_{3} / \mathrm{dppe} / \mathrm{Na}_{2} \mathrm{CO}_{3}$ in dioxane at room temperature. When the catalyst loading was decreased to $1 \mathrm{~mol} \%$, the reaction afforded the furanone 3 in $78 \%$ yield after<smiles>[AsH3-]N=Cc1ccccc1</smiles><smiles>CCOC(=O)CC(=O)CCl</smiles>

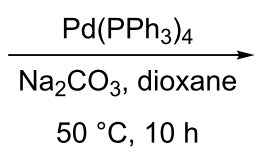

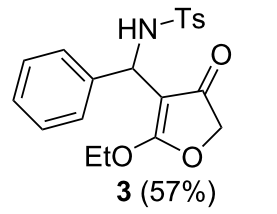<smiles>CCOC(=O)c1cc(O)c(C(=O)OCC)c(O)c1C</smiles>

Scheme 2: Pd-catalyzed synthesis of $3(2 H)$-furanone from tosylimine 1 a

Table 1: Optimisation studies ${ }^{\mathrm{a}}$.<smiles></smiles>

$1 a$<smiles>CCOC(=O)CC(=O)CCl</smiles>

2a<smiles>CCOC1=C(C([NH3+])c2ccccc2)C(=O)CO1</smiles>

$50{ }^{\circ} \mathrm{C}, 10 \mathrm{~h}$

3

\begin{tabular}{|c|c|c|c|c|}
\hline Entry & Catalyst & Ligand & Base & Yield $3^{b}(\%)$ \\
\hline 1 & $\mathrm{Pd}\left(\mathrm{PPh}_{3}\right)_{4}$ & - & $\mathrm{Na}_{2} \mathrm{CO}_{3}$ & 57 \\
\hline 2 & $\mathrm{Pd}\left(\mathrm{PPh}_{3}\right)_{4}$ & - & $\mathrm{K}_{2} \mathrm{CO}_{3}$ & 34 \\
\hline 3 & $\mathrm{Pd}\left(\mathrm{PPh}_{3}\right)_{4}$ & - & $\mathrm{KOt}-\mathrm{Bu}$ & $19^{c}$ \\
\hline 4 & $\mathrm{Pd}\left(\mathrm{PPh}_{3}\right)_{4}$ & $\mathrm{P}(\text { o-furyl })_{3}$ & $\mathrm{Na}_{2} \mathrm{CO}_{3}$ & 66 \\
\hline 5 & $\mathrm{Pd}\left(\mathrm{PPh}_{3}\right)_{4}$ & dppe & $\mathrm{Na}_{2} \mathrm{CO}_{3}$ & 70 \\
\hline 6 & $\mathrm{Pd}_{2} \mathrm{dba}_{3} \cdot \mathrm{CHCl}_{3}$ & - & $\mathrm{Na}_{2} \mathrm{CO}_{3}$ & 85 \\
\hline 7 & $\mathrm{Pd}_{2} \mathrm{dba}_{3} \cdot \mathrm{CHCl}_{3}$ & $\mathrm{P}(\text { o-furyl })_{3}$ & $\mathrm{Na}_{2} \mathrm{CO}_{3}$ & 82 \\
\hline 8 & $\mathrm{Pd}_{2} \mathrm{dba}_{3} \cdot \mathrm{CHCl}_{3}$ & dppe & $\mathrm{Na}_{2} \mathrm{CO}_{3}$ & 88 \\
\hline 9 & $\mathrm{Pd}_{2} \mathrm{dba}_{3} \cdot \mathrm{CHCl}_{3}$ & dppe & $\mathrm{Na}_{2} \mathrm{CO}_{3}$ & $80^{d}$ \\
\hline 10 & $\mathrm{Pd}_{2} \mathrm{dba}_{3} \cdot \mathrm{CHCl}_{3}$ & dppe & $\mathrm{Na}_{2} \mathrm{CO}_{3}$ & $84^{e}$ \\
\hline 11 & $\mathrm{Pd}_{2} \mathrm{dba}_{3} \cdot \mathrm{CHCl}_{3}$ & dppe & $\mathrm{Na}_{2} \mathrm{CO}_{3}$ & $43^{f}$ \\
\hline 12 & - & - & $\mathrm{Na}_{2} \mathrm{CO}_{3}$ & 65 \\
\hline 13 & $\mathrm{Pd}_{2} \mathrm{dba}_{3} \cdot \mathrm{CHCl}_{3}$ & dppe & - & trace \\
\hline 14 & $\mathrm{Pd}_{2} \mathrm{dba}_{3} \cdot \mathrm{CHCl}_{3}$ & dppe & $\mathrm{Na}_{2} \mathrm{CO}_{3}$ & $78^{g}$ \\
\hline
\end{tabular}

aReaction conditions: 1a (1.0 equiv), $2 \mathrm{a}$ (1.1 equiv), catalyst $(5 \mathrm{~mol} \%)$, ligand $(10 \mathrm{~mol} \%)$, base $\left(2.0\right.$ equiv), dioxane $(2 \mathrm{~mL}), 50{ }^{\circ} \mathrm{C}, 10 \mathrm{~h} .{ }^{\mathrm{b}} \mathrm{Isolated}$ yield. 'Dimerisation product 4 was formed in $27 \%$ yield. ${ }^{d} \mathrm{CH}_{3} \mathrm{CN}$ instead of dioxane. ${ }^{\mathrm{e}} \mathrm{THF}$ instead of dioxane. ${ }^{\mathrm{f}} \mathrm{rt}, 24 \mathrm{~h} .{ }^{\mathrm{g}} 1 \mathrm{~mol} \%$ of $\mathrm{Pd}_{2} \mathrm{dba}{ }_{3} \cdot \mathrm{CHCl}_{3}$, $5 \mathrm{~mol} \%$ of dppe. 
10 hours (Table 1 , entry 14). The catalytic role of palladium in the present transformation was proved by conducting two control experiments. The first reaction was performed only in the presence of base (Table 1, entry 12) and the second one only in the presence of the $\mathrm{Pd}_{2} \mathrm{dba}_{3} \cdot \mathrm{CHCl}_{3} /$ dppe combination (Table 1, entry 13). Furanone 3 was obtained in $65 \%$ yield from the first reaction whereas the second reaction afforded only trace amounts of the desired product. Thus we can see that under palladium catalysis there is an increase in the yield of $3(2 \mathrm{H})$-furanone 3 by $23 \%$ by comparing the first control experiment and the reaction depicted in entry 8 of Table 1 , thereby proving that palladium is catalyzing the reaction.

With optimal conditions in hand (imine (1.0 equiv), 4-chloroacetoacetate (1.1 equiv), $\mathrm{Pd}_{2} \mathrm{dba}_{3} \cdot \mathrm{CHCl}_{3}$ (5 mol \%), dppe (10 mol \%) $\mathrm{Na}_{2} \mathrm{CO}_{3}$ (2.0 equiv) in dioxane at $50{ }^{\circ} \mathrm{C}$ for $10 \mathrm{~h}$ ), studies towards the generality of the reaction were carried out with different imines $\mathbf{1} \mathbf{a}-\mathbf{c}$ derived from aromatic aldehydes with 4-chloro-acetoacetates $\mathbf{2 a}, \mathbf{b}$.
In all the cases substituted $3(2 H)$-furanones were obtained in good to excellent yields (Figure 2). The reaction was also extended to tosylimines derived from aliphatic aldehydes, pentanal (for 1d) and 3-phenylpropionaldehyde (for 1e) and thus we could rule out any influence of the aromatic moiety on the outcome of the reaction. The corresponding 4-susbtituted$3(2 \mathrm{H})$-furanones were obtained from these two substrates in good yields (Figure 2). We also tried a reaction with $N$-Boc protected imine under optimized conditions and the corresponding furanone was obtained in good yield (Figure 2, compound 14). The structure elucidation of the furanone products 3 , and 5-14 was accomplished by the usual spectroscopic methods (see Supporting Information File 1) and also by X-ray structure determination [43] for furanones 7 (product formed by the reaction of $\mathbf{1 b}$ with $\mathbf{2 b}$ ) and $\mathbf{1 0}$ (product formed by the reaction of 1d with 2a) (Figure 3).

We believe that the mechanism of the present furanone synthesis from imines is similar to that reported for activated

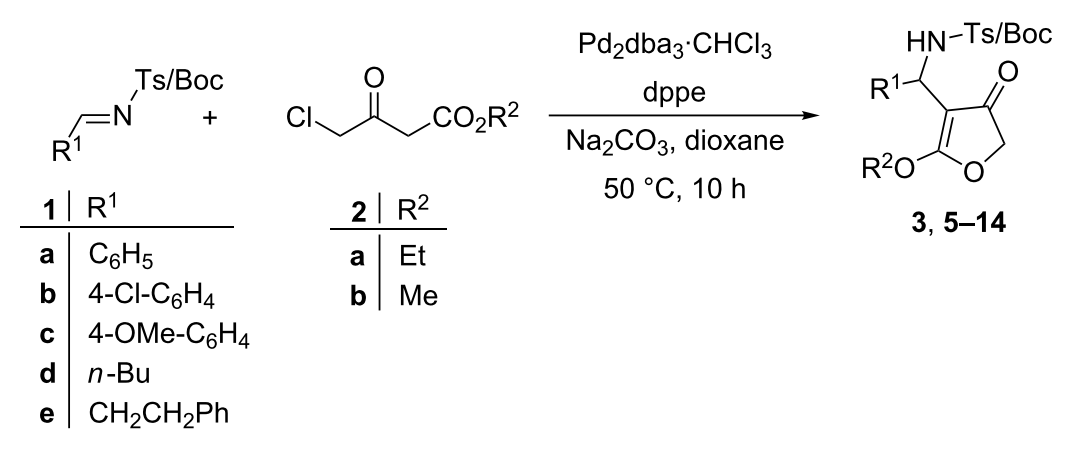<smiles>[13CH3]OC1=C(C([NH3+])c2ccccc2)C(=O)CO1</smiles><smiles>CCOC1=C(C([NH3+])c2ccc(OC)cc2)C(=O)CO1</smiles>

$8(71 \%)$

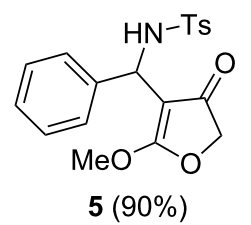

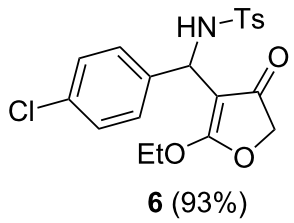<smiles>[NH3+]C(C1=C(O[Na])OCC1=O)c1ccc(Cl)cc1</smiles><smiles>COC1=C(C([NH3+])c2ccc(OC)cc2)C(=O)CO1</smiles>

$9(78 \%)$<smiles>CCCCC(N[NH3+])C1=C(OCC)OCC1=O</smiles>

$10(78 \%)$<smiles>CCCCC([NH3+])C1=C(O[13CH3])OCC1=O</smiles>

$11(80 \%)$<smiles>CCOC1=C(C(CCc2ccccc2)N[I-])C(=O)CO1</smiles><smiles>COC1=C(C(CCc2ccccc2)N[AsH3])C(=O)CO1</smiles>

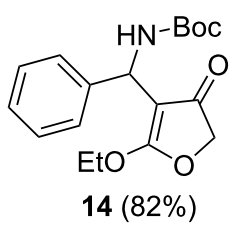

Figure 2: Generalisation with aromatic and aliphatic imines (reaction conditions: 1 (1.0 equiv), 2 (1.1 equiv), $\mathrm{Pd}_{2} \mathrm{dba}_{3} \cdot \mathrm{CHCl}_{3}(5 \mathrm{~mol} \%$ ), dppe $(10 \mathrm{~mol} \%), \mathrm{Na}_{2} \mathrm{CO}_{3}$ (2.0 equiv), dioxane $(2 \mathrm{~mL}), 50^{\circ} \mathrm{C}, 10 \mathrm{~h}$, isolated yield). 

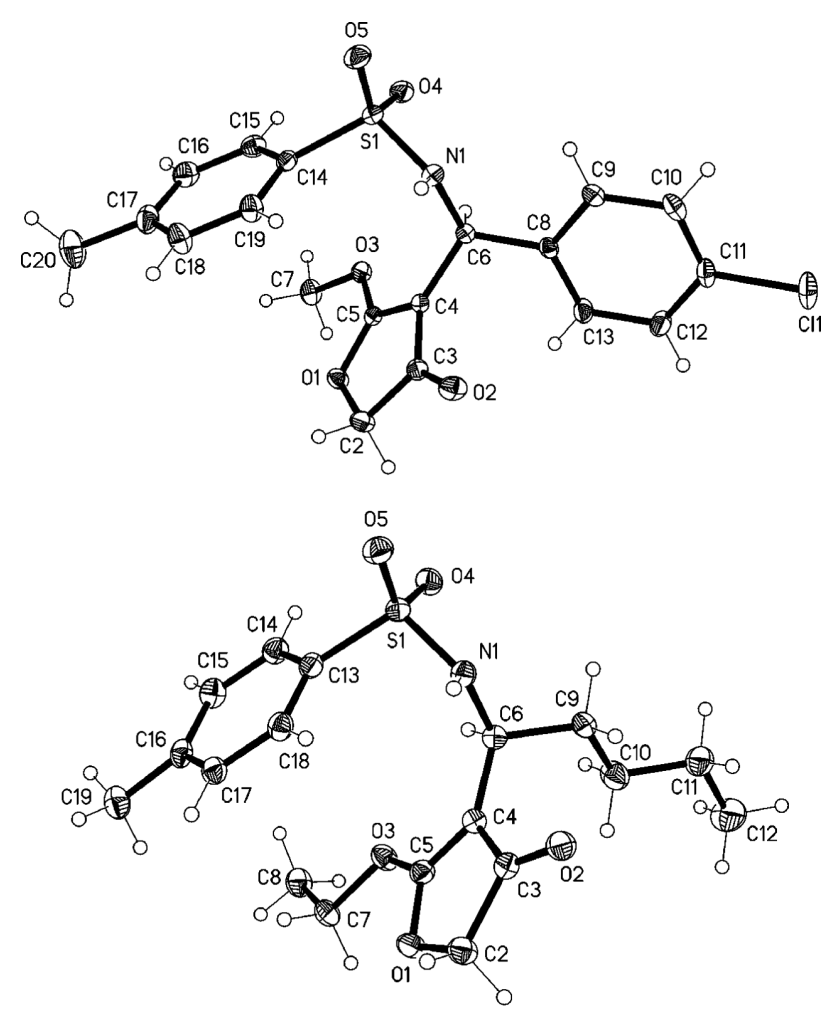

Figure 3: Thermal ellipsoid diagrams (50\% probability levels) of 4-substituted-3(2H)-furanones 7 (above) and 10 (below).

alkenes [40]. This tandem protocol has two steps, the first being a Mannich addition of the enolate to the imine. To find out whether Mannich addition is palladium catalyzed, we carried out two reactions of tosylimine $\mathbf{1 a}$ with methyl acetoacetate. The first transformation was carried out under basic conditions $\left(\mathrm{Na}_{2} \mathrm{CO}_{3}\right.$ (1.0 equiv), dioxane, $50{ }^{\circ} \mathrm{C}, 6 \mathrm{~h}$ ) and the second under optimized conditions. Both reactions afforded the Mannich addition product in similar yields, proving that Mannich addition was uncatalyzed.

Based on these results, we propose a plausible mechanism for $3(2 \mathrm{H})$-furanone synthesis from tosylimines and 4-chloroacetoacetate (Scheme 3). The reaction starts with the Mannich addition of the enolate $\mathbf{1 5}$ to the carbon atom of the imine double bond to form intermediate 16. This step is the same for both the catalyzed and the uncatalyzed pathway. The second step of the catalyzed route involves the oxidative addition of $\operatorname{Pd}(0) \mathrm{L}_{n}$ to the $\mathrm{C}-\mathrm{Cl}$ bond of Mannich adduct $\mathbf{1 6}$ to form $\mathbf{1 7}$. The oxy- $\pi$-allylpalladium intermediate $\mathbf{1 8}$ can then be formed from intermediate 17 [4-8]. The final step of the catalyzed mechanism, i.e., the ring closure towards the formation of $3(2 H)$-furanone is initiated by the abstraction of the acidic proton by the base and consequent ester enolate attack to the end carbon of the oxy- $\pi$ allylpalladium intermediate.
Having established an efficient method for the synthesis of highly functionalized furanones from imines, we were interested next in extending the range of the electrophiles by introducing different functionalities at the 4-position of the $3(2 \mathrm{H})$ furanone. We chose to check the reactivity of diisopropylazodicarboxylate (19a) with ethyl 4-chloroacetoacetate (2a) under palladium catalysis. In the initial reaction, 19a was treated with 2a in the presence of $\mathrm{Pd}\left(\mathrm{PPh}_{3}\right)_{4}$ as catalyst and base $\left(\mathrm{K}_{2} \mathrm{CO}_{3}\right)$ in dioxane at $50{ }^{\circ} \mathrm{C}$. After 10 hours, the expected product 4-hydrazino-3 $(2 H)$-furanone 20 was isolated in 58\% yield (Scheme 4).

Table 2 describes the screening of different reaction conditions to improve the yield of 20. First we tested the efficacy of different bases $\mathrm{K}_{2} \mathrm{CO}_{3}, \mathrm{Na}_{2} \mathrm{CO}_{3}$ and $\mathrm{KO} t$ - $\mathrm{Bu}$, of which $\mathrm{Na}_{2} \mathrm{CO}_{3}$ proved to be the best (Table 2, entries 1-3). The highest yield for 4-hydrazino-3(2H)-furanone was given when $\mathrm{Pd}\left(\mathrm{PPh}_{3}\right)_{4}$ alone was used among different catalyst/ligand combinations tested with $\mathrm{Pd}\left(\mathrm{PPh}_{3}\right)_{4}$ and $\mathrm{Pd}_{2} \mathrm{dba}_{3} \cdot \mathrm{CHCl}_{3}$ as catalysts and dppe and $\mathrm{P}(o \text {-furyl })_{3}$ as ligands (Table 2 , entries 2 , and $\left.4-8\right)$. The product was obtained in better yields when dioxane was used as the solvent (Table 2, entries 2, 9 and 10). At room temperature the reaction with optimised catalyst/solvent system furnished only $38 \%$ of the substituted furanone even after 24 hours 


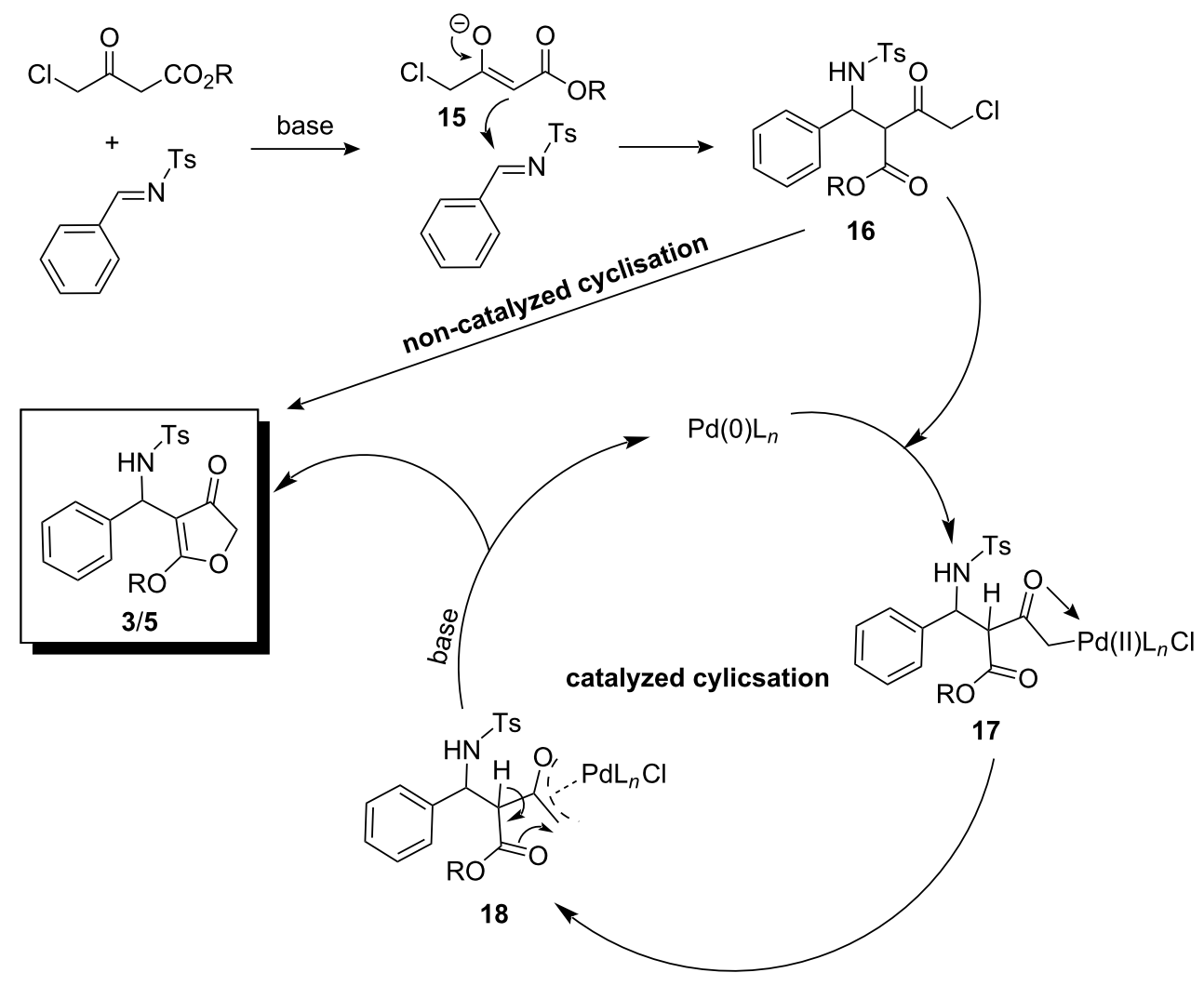

Scheme 3: Mechanism of formation of the $3(2 H)$-furanone derivative from an imine.

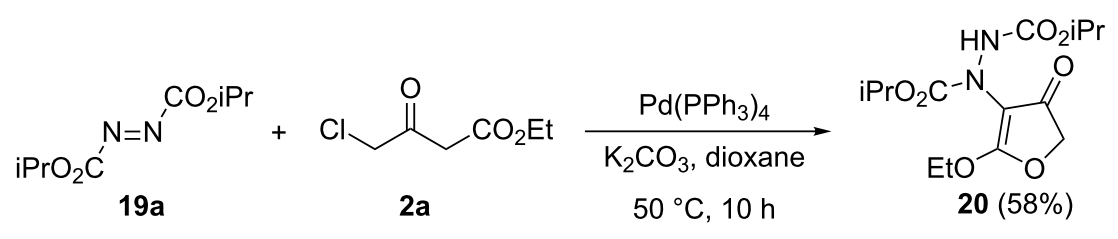

Scheme 4: Pd-catalyzed synthesis of $3(2 H)$-furanone from diazoester $19 a$.

(Table 2, entry 11). A control experiment was done without the catalyst/ligand combination but only in the presence of base, which afforded the furanone in $69 \%$ yield (Table 2, entry 12). Thus by comparing the control experiment and the reaction depicted in entry 2 of Table 2 we can confirm that palladium catalyzes the reaction.

The generality of the reaction was checked with different diazo esters 19a-c with 4-chloroacetoacetate esters $\mathbf{2 a}$ and $\mathbf{2 b}$ under the optimized conditions (diazo ester (1.0 equiv), 4-chloroacetoacetate (1.1 equiv), $\mathrm{Pd}\left(\mathrm{PPh}_{3}\right)_{4}(5 \mathrm{~mol} \%), \mathrm{Na}_{2} \mathrm{CO}_{3}$ (2.0 equiv) in dioxane at $50{ }^{\circ} \mathrm{C}$ for $10 \mathrm{~h}$ ). All reactions afforded the corresponding 4-hydrazino-3 $(2 H)$-furanones in excellent yields (Figure 4).
The possibility for further functionalization of 4-substitued furanones was checked by treating 11 with $n$-heptylamine in $\mathrm{MeOH}$ at $40{ }^{\circ} \mathrm{C}$. After 10 hours the aza-prostaglandin analogue [26] 27 was isolated in $85 \%$ yield (Scheme 5).

\section{Conclusion}

We have developed an efficient protocol for the synthesis of 4-substituted 3(2H)-furanones by the reaction of imines or diazo esters with 4-chloroacetoacetates under palladium catalysis. We could extend the reaction to imines derived from aromatic and aliphatic aldehydes. The reaction proceeded via a catalyzed tandem Mannich addition-palladium-catalyzed ring-closing pathway to afford various $3(2 H)$-furanones in good to excellent yields. We could further apply this route to the preparation of an 
Table 2: Optimisation studies ${ }^{\mathrm{a}}$.

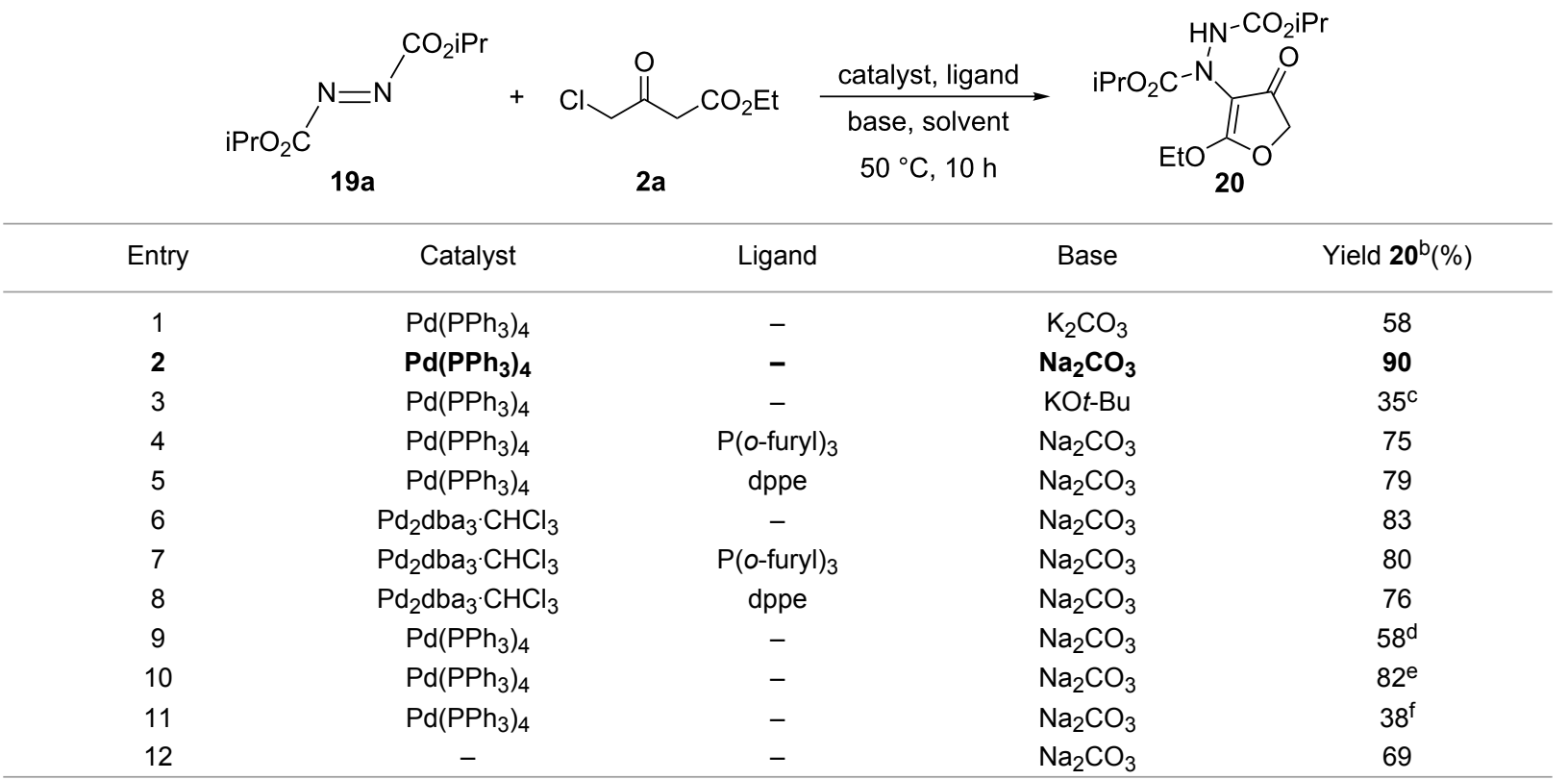

aReaction conditions: 19a (1.0 equiv), $2 \mathrm{a}$ (1.1 equiv), catalyst $(5 \mathrm{~mol} \%)$, ligand $(10 \mathrm{~mol} \%)$, base $\left(2.0\right.$ equiv), dioxane $(2 \mathrm{~mL}), 50{ }^{\circ} \mathrm{C}, 10 \mathrm{~h} .{ }^{\mathrm{b}} \mathrm{Isolated}$ yield. 'Dimerization product 4 was formed in $23 \%$ yield. ${ }^{\mathrm{d}} \mathrm{CH}_{3} \mathrm{CN}$ instead of dioxane. ${ }^{\mathrm{e}} \mathrm{THF}$ instead of dioxane. ${ }^{\mathrm{f}} \mathrm{rt}, 24 \mathrm{~h}$.

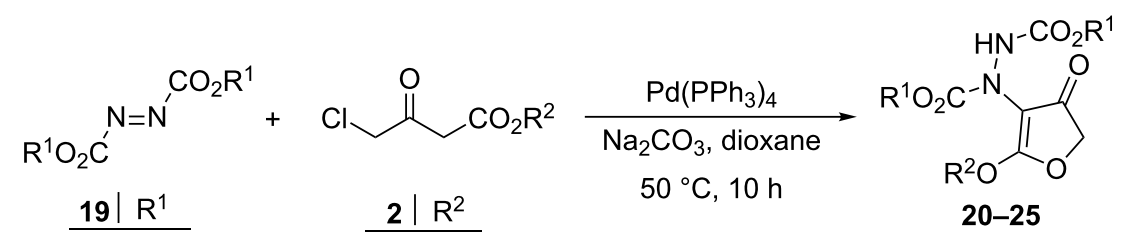

$$
\begin{aligned}
& \begin{array}{l|lll}
\text { a } & i P r & \text { a } & \text { Et }
\end{array} \\
& \text { b Et } \quad \text { b } \\
& \text { c } t \text {-Bu }
\end{aligned}
$$<smiles>CCOC1=C(N(NC(=O)OC(C)C)C(=O)OC(C)C)C(=O)CO1</smiles>

$20(90 \%)$<smiles>CCOC(=O)NN1C(=O)CC(=O)C1=O</smiles>

$23(92 \%)$<smiles>COC(=O)N(NC(=O)OC(C)C)C1=C(OC)OCC1=O</smiles>

$21(94 \%)$<smiles>CCOC(=O)NC1=C(NC(=O)OCC)C(=O)CO1</smiles>

$24(86 \%)$<smiles>CCOC(=O)NN1C(=O)COC1=O</smiles>

22 (90\%)<smiles>COC(=O)N(NC(=O)OC(C)(C)C)C1=C(OC)OCC1=O</smiles>

25 (86\%) 


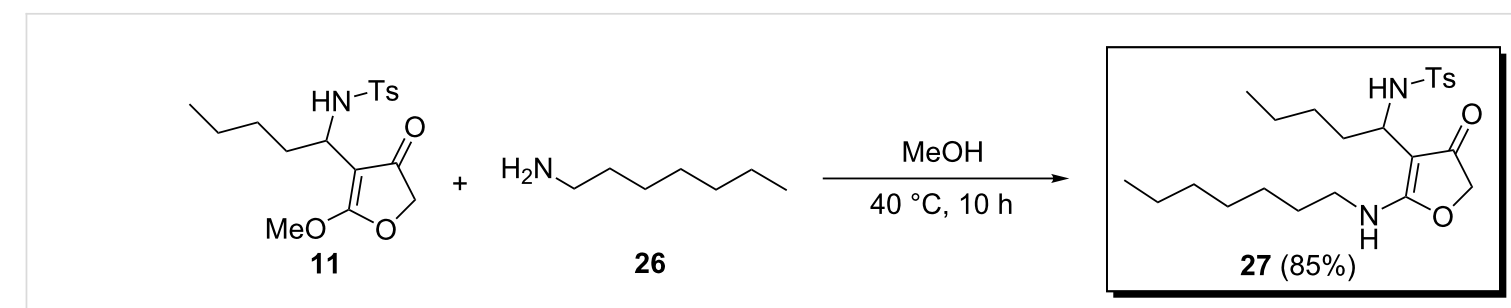

Scheme 5: Synthesis of aza-prostaglandin analogue.

aza-prostaglandin analogue. The synthesized molecules are currently being screened for biological activities. We have also extended the reaction to triple-bonded electrophiles such as acetylenes, benzyne and nitriles; the results will be reported in due course. Studies are in progress to develop a stereoselective version of the process.

\section{Supporting Information}

\section{Supporting Information File 1}

Experimental part and NMR spectra.

[http://www.beilstein-journals.org/bjoc/content/

supplementary/1860-5397-10-150-S1.pdf]

\section{Acknowledgements}

$\mathrm{JJ}$ thanks the Alexander von Humboldt foundation for a postdoctoral fellowship.

\section{References}

1. Guo, H.-C.; Ma, J.-A. Angew. Chem., Int. Ed. 2006, 45, 354-366. doi:10.1002/anie.200500195

2. Tietze, L. F. Chem. Rev. 1996, 96, 115-136. doi:10.1021/cr950027e

3. Perlmutter, P. Conjugate Addition Reactions in Organic Synthesis; Pergamon: Oxford, 1992.

4. Ogoshi, S.; Morimoto, T.; Nishio, K.; Ohe, K.; Murai, S. J. Org. Chem. 1993, 58, 9-10. doi:10.1021/jo00053a004

5. Ikeda, I.; Ohsuka, A.; Tani, K.; Hirao, T.; Kurosawa, H. J. Org. Chem. 1996, 61, 4971-4974. doi:10.1021/jo951425k

6. Stille, J. K.; Wong, P. K. J. Org. Chem. 1975, 40, 532-534. doi:10.1021/jo00892a044

7. Negishi, E.; de Meijere, A., Eds. Handbook of Organopalladium Chemistry for Organic Synthesis; John Wiley \& Sons: New York, 2002; Vol. 1 and 2.

8. Patil, N. T.; Yamamoto, Y. Top. Organomet. Chem. 2006, 19, 91-113. doi:10.1007/3418_014

9. Curran, D. P.; Singleton, D. H. Tetrahedron Lett. 1983, 24, 2079-2082. doi:10.1016/S0040-4039(00)81849-3

10. Wolff, S.; Agosta, W. C. Tetrahedron Lett. 1985, 26, 703-704. doi:10.1016/S0040-4039(00)89113-3

11. Saimoto, H.; Hiyama, T.; Nozaki, H. J. Am. Chem. Soc. 1981, 103, 4975-4977. doi:10.1021/ja00406a066

12. Jackson, R. F. W.; Raphael, R. A. J. Chem. Soc., Perkin Trans. 1 1984, 535-539. doi:10.1039/p19840000535
13. Kupchan, S. M.; Sigel, C. W.; Matz, M. J.; Gilmore, C. J.; Bryan, R. F. J. Am. Chem. Soc. 1976, 98, 2295-2300. doi:10.1021/ja00424a050

14. Smith, A. B., III; Guaciaro, M. A.; Schow, S. R.; Wovkulich, P. M.; Toder, B. H.; Hall, T. W. J. Am. Chem. Soc. 1981, 103, 219-222. doi:10.1021/ja00391a054

15. Smith, A. B., III; Levenberg, P. A.; Jerris, P. J.; Scarborough, R. M., Jr.; Wovkulich, P. M. J. Am. Chem. Soc. 1981, 103, 1501-1513. doi:10.1021/ja00396a034

16. Dreyer, D. L.; Lee, A. Phytochemistry 1972, 11, 763-767. doi:10.1016/0031-9422(72)80045-1

17. Jerris, P. J.; Smith, A. B., III. J. Org. Chem. 1981, 46, 577-585. doi:10.1021/jo00316a018

18. Haug, T. T.; Kirsch, S. F. In Targets in Heterocyclic Systems; Attanasi, O. A.; Spinelli, D., Eds.; Royal Society of Chemistry: Cambridge, 2009; Vol. 13, pp 57-91.

See for a book chapter on synthesis and chemistry of 3-(2H)-furanone.

19. Mack, R. A.; Zazulak, W. I.; Radov, L. A.; Baer, J. E.; Stewart, J. D.; Elzer, P. H.; Kinsolving, C. R.; Georgiev, V. S. J. Med. Chem. 1988, 31, 1910-1918. doi:10.1021/jm00118a008

20. Felman, S. W.; Jirkovsky, I.; Memoli, K. A.; Borella, L.; Wells, C.; Russell, J.; Ward, J. J. Med. Chem. 1992, 35, 1183-1190. doi:10.1021/jm00085a003

21. Jackson, R. F. W.; Raphael, R. A. Tetrahedron Lett. 1983, 24 , 2117-2120. doi:10.1016/S0040-4039(00)81859-6

22. Villemin, D.; Jaffrès, P.-A.; Hachémi, M. Tetrahedron Lett. 1997, 38, 537-538. doi:10.1016/S0040-4039(96)02365-9

23. Sakamoto, H. T.; Flausino, D.; Castellano, E. E.; Stark, C. B. W.; Gates, P. J.; Lopes, N. P. J. Nat. Prod. 2003, 66, 693-695. doi:10.1021/np020314v

24. Shin, S. S.; Byun, Y.; Lim, K. M.; Choi, J. K.; Lee, K.-W.; Moh, J. H.; Kim, J. K.; Jeong, Y. S.; Kim, J. Y.; Choi, Y. H.; Koh, H.-J.; Park, Y.-H.; Oh, Y. I.; Noh, M.-S.; Chung, S. J. Med. Chem. 2004, 47, 792-804. doi:10.1021/jm020545z

25. Shamshina, J. L.; Snowden, T. S. Tetrahedron Lett. 2007, 48, 3767-3769. doi:10.1016/j.tetlet.2007.03.166

26. Pashkovskii, F. S.; Shchukina, E. M.; Gribovskii, M. G.; Lakhvich, F. A. Russ. J. Org. Chem. 2006, 42, 527-540. doi:10.1134/S1070428006040087

27. Henry, D. W.; Silverstein, R. M. J. Org. Chem. 1966, 31, 2391-2394. doi:10.1021/jo01345a506

28. Antonioletti, R.; Bonadies, F.; Prencipe, T.; Scettri, A. J. Chem. Soc., Chem. Commun. 1988, 850-851. doi:10.1039/c39880000850

29. Winkler, J. D.; Oh, K.; Asselin, S. M. Org. Lett. 2005, 7, 387-389. doi:10.1021/ol047810q

30. Poonoth, M.; Krause, N. J. Org. Chem. 2011, 76, 1934-1936. doi:10.1021/jo102416e 
31. Liu, Y.; Liu, M.; Guo, S.; Tu, H.; Zhou, Y.; Gao, H. Org. Lett. 2006, 8, 3445-3448. doi:10.1021/ol061059z

32. Crone, B.; Kirsch, S. F. J. Org. Chem. 2007, 72, 5435-5438. doi:10.1021/jo070695n

33. Egi, M.; Azechi, K.; Saneto, M.; Shimizu, K.; Akai, S. J. Org. Chem. 2010, 75, 2123-2126. doi:10.1021/jo100048j

34. Kirsch, S. F.; Binder, J. T.; Liébert, C.; Menz, H. Angew. Chem., Int. Ed. 2006, 45, 5878-5880. doi:10.1002/anie.200601836

35. Bunnelle, E. M.; Smith, C. R.; Lee, S. K.; Singaram, S. W.; Rhodes, A. J.; Sarpong, R. Tetrahedron 2008, 64, 7008-7014. doi:10.1016/j.tet.2008.02.103

36. Silva, F.; Reiter, M.; Mills-Webb, R.; Sawicki, M.; Klär, D.; Bensel, N.; Wagner, A.; Gouverneur, V. J. Org. Chem. 2006, 71, 8390-8394. doi:10.1021/jo061292a

37. Marson, C. M.; Edaan, E.; Morrell, J. M.; Coles, S. J.; Hursthouse, M. B.; Davies, D. T. Chem. Commun. 2007, 2494-2496. doi:10.1039/b701548h

38. Dou, X.; Han, X.; Lu, Y. Chem.-Eur. J. 2012, 18, 85-89. doi:10.1002/chem.201102796

39. Yan, Y.-Y.; Lu, R.-J.; Wang, J.-J.; Xuan, Y.-N.; Yan, M. Tetrahedron 2012, 68, 6123-6130. doi:10.1016/j.tet.2012.05.082

40. John, J.; Hopf, H. Eur. J. Org. Chem. 2013, 841-845. doi:10.1002/ejoc.201201253

41. Luo, N.-H.; Sun, X.; Yan, Y.-Y.; Nie, S.-Z.; Yan, M. Tetrahedron: Asymmetry 2011, 22, 1536-1541. doi:10.1016/j.tetasy.2011.08.022

42. Delgada-Rebollo, M.; Moreno, R.; Fructos, M. R.; Prieto, A. Eur. J. Org. Chem. 2013, 31-34. doi:10.1002/ejoc.201201252

43. Crystallographic data have been deposited with the Cambridge Crystallographic Data Centre as supplementary publications no. CCDC-922077 (7), -922078 (10). Copies of the data can be obtained free of charge from http://www.ccdc.cam.ac.uk/data_request/cif

\section{License and Terms}

This is an Open Access article under the terms of the Creative Commons Attribution License (http://creativecommons.org/licenses/by/2.0), which permits unrestricted use, distribution, and reproduction in any medium, provided the original work is properly cited.

The license is subject to the Beilstein Journal of Organic Chemistry terms and conditions:

(http://www.beilstein-journals.org/bjoc)

The definitive version of this article is the electronic one which can be found at: $\underline{\text { doi: } 10.3762 / \text { bjoc. } 10.150}$ 